Krzysztof Dyrek*

Częstochowa

Zbigniew Marek**

Kraków

\title{
Edukacja do przebaczenia w pedagogii ignacjańskiej
}

Przebaczenie wyraża rzeczywistość, która zdaje się być podstawą budowania między ludźmi harmonii. Mamy przy tym świadomość, że umiejętność przebaczenia człowiek nabywa z wielkim trudem. Niejednokrotnie też nie jest w stanie zdobyć się na ten heroiczny akt. Wszystko to skłania do refleksji nad tym, czy można - a jeśli tak, to w jaki sposób - kierować procesami wychowania, tak by człowiek dorastał w swoim życiu do kierowania się i okazywania innym przebaczenia.

W artykule zamierzamy przybliżyć proponowane przez pedagogię ignacjańską rozwiązania problematyki związanej z przebaczeniem. Mamy świadomość, że wypracowane $\mathrm{w}$ tej pedagogii zasady same $\mathrm{z}$ siebie nie są w stanie przekazać człowiekowi umiejętności przebaczania. Ich rolą jest wskazywanie drogi wewnętrznej przemiany, życiowych przewartościowań, które umożliwią zdobycie się na tego rodzaju akty.

* Ks. dr Krzysztof Dyrek SJ jest współtwórcą i dyrektorem Szkoły Formatorów przy Akademii Ignatianum w Krakowie, obecnie pracuje w Centrum Duchowości im. Św. Ignacego Loyoli w Częstochowie. Adres: Centrum Duchowości - Księża Jezuici, ul. Św. Kingi 74/84, 42-226 Częstochowa; e-mail: kdyrek@jezuici.pl.

** Ks. prof. zw. dr hab. Zbigniew Marek jest profesorem w Katedrze Andragogiki i Aksjologii Pedagogicznej w Instytucie Nauk o Wychowaniu Akademii Ignatianum w Krakowie. Adres: Akademia Ignatianum, ul. Kopernika 26, 31-501 Kraków; e-mail: zmarek23@gmail. com. 
Przy opisywaniu założeń pedagogii ignacjańskiej, które pomagają człowiekowi zrozumieć, czym jest przebaczenie, dlaczego należy przebaczać i co z takiego aktu wynika, będziemy się posługiwać terminem „edukacja”. Pod tym pojęciem będziemy rozumieć wszelkiego rodzaju procesy społeczne, które służą formowaniu (zmianie, rozwijaniu) zdolności człowieka albo też zmianie ich jakości ${ }^{1}$. Chodzi przy tym o zaznaczenie stopnia ogólności i niejednorodności opisywanej problematyki, którą wpisujemy w ogół oddziaływań wspierających człowieka w jego funkcjonowaniu społecznym ${ }^{2}$. O wyborze tego pojęcia zadecydowała jego nadrzędna, a jednocześnie znaczeniowa bliskość terminom „wychowanie” i „kształcenie”. Termin „edukacja” będziemy stosować zamiennie z terminem „formacja”", który pochodzi od łacińskiego słowa formatio i oznacza ukształtowanie, utworzenie, wywieranie trwałych wpływów na osobowość człowieka przez jedną osobę, grupę czy instytucję ${ }^{5}$. Pojęcie to bywa używane w literaturze pedagogicznej ${ }^{6}$, chociaż częściej posługują się nim autorzy piszący o sprawach religijnych. Edukacja obejmuje zarówno sferę psychiki, jak też umysłu, sumienia, religijności człowieka. W przypadku pedagogii ignacjańskiej czynnikiem integrującym całokształt procesów edukacyjnych jest formacja duchowa i religijna, która dzięki poznawaniu przez osobę własnej niedojrzałości, świadomości zranień emocjonalnych i moralnych, u Boga poszukuje uzdrawiającej mocy ${ }^{7}$

${ }^{1}$ Por. Bogusław Milerski, Religia a szkoła. Status edukacji religijnej w szkole w ujęciu ewangelickim (Warszawa: Chrześcijańska Akademia Teologiczna, 1998),125.

${ }^{2}$ Krzysztof Rubacha, „Edukacja jako przedmiot pedagogiki i jej subdyscyplin”, w: Pedagogika. Podręcznik akademicki, t. 1, red. Zbigniew Kwieciński, Bogusław Śliwerski (Warszawa: PWN, 2005), 21.

3 Jarosław Michalski, Edukacja i religia jako źródło rozwoju egzystencjalno-kognitywnego. Studium hermeneutyczno-krytyczne (Toruń: Wydawnictwo UMK, 2004), 51; Gerald L. Gutek, Filozoficzne i ideologiczne podstawy edukacji (Gdańsk: Gdańskie Wydawnictwo Psychologiczne, 2003), 14.

4 Termin ten jest rzadko odnoszony do wychowania. Nie uwzględniono go między innymi w Wielkiej Encyklopedii PWN (2002).

${ }^{5}$ Zdzisław Chlewiński, „Formacja”, w: Encyklopedia katolicka, t. V (Lublin: TN KUL, 2004), 389.

${ }^{6}$ Marian Nowak, Pedagogiczny profil nauk o wychowaniu (Lublin, Wydawnictwo KUL, 2012), 262-263.

7 Por. Józef Augustyn, „Ćwiczenia duchowne jako podstawa pedagogiki ignacjańskiej”, w: Pedagogika ignacjańska. Historia, teoria, praktyka, red. Anna Królikowska (Kraków: WSFP Ignatianum, WAM, 2010), 17-19. 
po to, by podołać służącym duchowemu wzrostowi życiowym wyborom ${ }^{8}$. W tym sensie formacja ma osobie umożliwiać nabywanie przekonań i wartości, które będą ją wspierać w osiągnięciu zamierzonych umiejętności, pomagających w przejmowania ról społecznych i zawodowych'. Dlatego też można uważać ją za podstawę dla procesów edukacji do przebaczenia.

\section{Pedagogia ignacjańska i jej założenia}

Pedagogia ignacjańska wyrasta z duchowości, którą zaproponował założyciel zakonu jezuitów - Ignacy Loyola (1491-1556). Duchowość Ignacego, zwana od jego imienia duchowością ignacjańską, ma swoje korzenie w religijnych doświadczeniach Ignacego, którymi dzieli się w książeczce Ćwiczenia duchowne ${ }^{10}$. Termin „duchowość” pojawił się w literaturze chrześcijańskiej już w V wieku. Pochodzi od łacińskiego słowa spiritualitas. Początkowo posługiwano się nim wyłącznie w znaczeniu religijnym dla oznaczenia wzrostu duchowego człowieka. Współcześnie oznacza nie tylko praktykę życia duchowego i usystematyzowaną refleksję nad życiem duchowym, ale też praktykę ludzkiego życia, niełączonego z transcendencją-Bogiem. W tym przypadku mówimy o duchowości naturalnej ${ }^{11}$.

Termin „duchowość” jest pojęciem prostym i niedefiniowalnym ${ }^{12}$. Przy jego pomocy objaśniana jest ludzka egzystencja ${ }^{13}$, ukierunkowana na zapewnienie sobie szczęścia, miłości i życia ${ }^{14}$. Występująca w tym pojęciu końcówka „-ość” wyraża, zdaniem Marka Chmielewskiego, ,jakość wsobną, a więc coś, co istnieje samo w sobie, samoistnie, niejako substancjalnie, w odróż-

${ }^{8}$ Podstawy edukacji ignacjańskiej, tłum. Bogusław Steczek (Kraków: WSFP Ignatianum, WAM, 2006), 113.

${ }^{9}$ Chlewiński, „Formacja”, 389.

${ }^{10}$ Por. Zbigniew Marek, Religia - pomoc czy zagrożenie dla edukacji? (Kraków: WAM, 2014), $165 \mathrm{n}$.

${ }^{11}$ Marek Chmielewski, „Duchowość”, w: Leksykon duchowości katolickiej, red. Marek Chmielewski (Lublin-Kraków: Wydawnictwo „M”, 2002), 226-227.

12 Por. tamże, 229.

${ }^{13}$ Lidia Marszalek, Duchowość dziecka. Znaczenia * Perspektywy * Konteksty w pedagogice przedszkolnej (Warszawa: Mazowieckie Centrum Poligrafii, 2013), 27 n.

${ }^{14}$ Por. Luis F. Ladaria, Wprowadzenie do antropologii teologicznej (Kraków: WAM, 2002), 14-15; Anna Gałdowa, Aleksander Nelicki, „O możliwościach i warunkach bycia twórczym z perspektywy aksjologicznej teorii wartości”, Zeszyty Naukowe Uniwersytetu Jagiellońskiego. Prace Psychologiczne 8 (1993): 7-28. 
nieniu od jakości relatywnych, wyrażonych za pomocą przymiotnika (np.: czystość - czyste naczynie, sprawiedliwość - sprawiedliwy, złość - zły, itd.). Pojęcie to wprowadza zatem obiektywizowanie rzeczywistości, wskazując przy tym na cechę jednostkowego doświadczenia"15. Z tych też powodów współcześnie jest ono łączone z funkcjonowaniem człowieka, z jego przekonaniami, postawami i uznawanymi wartościami.

Duchowość ignacjańska ${ }^{16}$ określa pewien styl ludzkiego życia, sposób myślenia człowieka, jego postępowania, działania, reagowania, patrzenia na świat, uznawania określonych wartości, ideałów, a także sposób podejścia do innych osób i społeczności ${ }^{17}$. Właściwością tak rozumianej duchowości jest między innymi to, że nie podaje ona gotowych recept na udane życie, a tylko formuje człowieka do przyjęcia otwartej postawy, wolnej od nieuporządkowanych przywiązań, na rzecz szukania woli Boga w dostępnych sobie warunkach życia ${ }^{18}$. Za charakterystyczne rysy tej duchowości Bogusław Steczek uważa ukierunkowanie na teocentryzm, chrystocentryzm, maryjność, eklezjologię, uporządkowanie życia i prawdziwą wolność, rozeznanie woli Boga, mistykę służby, magis w działaniu, kontemplacyjność w działaniu, hojność i zaufanie Bogu oraz miłość i gotowość do służby we wszystkim ${ }^{19}$.

Troskę Ignacego Loyoli o rozwój duchowy człowieka należy łączyć z naturalnymi jego potrzebami rozumienia sensu życia. Jego świadomość uzdalnia bowiem osobę do przekraczania granic własnej ograniczoności. To z kolei pokazuje, że duchowość człowieka wyraża się w jego sposobie życia, który kształtują zajmowane przez niego postawy, pielęgnowane zwyczaje $i$ tradycje oraz respektowane wartości ${ }^{20}$. Wszystko to kreśli przed nim „drogę postępowania", promującą wizję życia, refleksyjny stosunek do codzienności, pełne szacunku nastawienie do świata, a w przypadku wierzących daje też nadzieję pełnego odnalezienia Boga (nieśmiertelności). Takie postrzeganie człowieka odnajdujemy we wspomnianej książeczce Ćwiczenia $d u$ chowne, której treścią są rady, przestrogi i wskazania, odnoszące się do życia wewnętrznego chrześcijanina. Jej oryginalność polega na metodycznym przekazie treści służących formacji (edukacji) człowieka poprzez integralne

15 Chmielewski, „Duchowość”, 226.

${ }^{16}$ Nazwa zaczerpnięta jest od imienia założyciela jezuitów.

17 Bogusław Steczek, „Charakterystyczne rysy duchowości ignacjańskiej - inspiracja dla rozwoju człowieka", w: Pedagogika wiary (Kraków: WSFP Ignatianum, WAM, 2007), 74.

18 Tamże, 80.

19 Por. tamże, 73-84.

${ }^{20}$ Dawid L. Fleming, Czym jest duchowość ignacjańska? (Kraków: WAM, 2013), 5-6. 
kształtowanie jego sfery somatycznej, psychicznej i duchowej. Celem tak udzielanego wsparcia jest uczynienie człowieka zdolnym do włączenia się w służbę Bogu i osiągnięcia swego celu ostatecznego, jakim jest życie z Nim.

Czasem intensywnej refleksji nad sobą, a także podejmowania działań o charakterze formacyjnym, są proponowane przez Ignacego Loyolę „ćwiczenia duchowe". Za ich pośrednictwem człowiek ma uczyć się rozpoznawać otaczającą go rzeczywistość „oczyma Boga” - z perspektywy Jego zbawczych działań. Refleksji tej towarzyszy przywoływanie doświadczeń własnej osoby po to, aby rozeznać dokąd „Duch Boży go prowadzi”. Oczekiwanie to domaga się od osoby wewnętrznego wysiłku przetrawienia treści podawanych przez prowadzącego ,ćwiczenia” zarówno w sferze intelektualnej, jak i emocjonalnej oraz wolitywnej. Proces ten rozpoczynają działania zmierzające do uspokojenia i uporządkowania zarówno sfery emocjonalnej, jak i duchowej ${ }^{21}$. Aby jednak mogło dojść do takiego rozpoznania, konieczne jest „nawrócenie” człowieka: wybór i spotkanie transcendentnego, osobowego Boga ${ }^{22}$. W następstwie tego procesu dochodzi do wyboru życiowej drogi, w którym respektowane jest Boże prawo ${ }^{23}$. Wybór ten ułatwia kolejne życiowe wybory, które przyczyniają się do duchowego wzrostu osoby ${ }^{24}$.

Podane przez Ignacego Loyolę w Ćwiczeniach duchownych zasady towarzyszenia osobie w jej rozwoju duchowym stały się podstawą wypracowanego przez jezuitów systemu formacji chrześcijańskiej. Zawiera on zasady udzielania osobie wsparcia do zrozumienia prawdy o ostatecznym przeznaczeniu człowieka do życia z Bogiem. Zasady te stały się fundamentem pedagogii nazwanej ,ignacjańską”, którą jezuici posługują się w pracy duszpasterskiej, a także w edukacyjnej. Jeden z najlepszych znawców pedagogii ignacjańskiej - Vincent J. Duminuco - określa ją jako drogę, na której nauczyciele towarzyszą uczniom w ich wzroście i rozwoju. Wyjaśnia, że nie można jej, podobnie jak sztuki i nauki o nauczaniu, sprowadzić do samej me-

${ }^{21}$ Por. Augustyn, „Ćwiczenia, 17-19.

22 Por. Marek Wójtowicz, „Dynamika Ćwiczeń duchownych św. Ignacego Loyoli w ujęciu Gillesa Cussona", w: Pedagogika ignacjańska. Historia, teoria, praktyka, red. Anna Królikowska (Kraków: WSFP Ignatianum, WAM, 2010), 58-62.

${ }^{23}$ Por. Rogelio García Mateo, ,Wielkie pragnienia i ideały człowieka według św. Ignacego Loyoli. U podstaw pedagogii magis", w: Pedagogika ignacjańska wobec wyzwań współczesnego humanizmu, red. Wit Pasierbek (Kraków: WSFP Ignatianum, WAM, 2008), 139-156; Wojciech Żmudziński, „Fundament ignacjańskiej pedagogiki”, w: Pedagogika ignacjańska wobec wyzwań współczesnego humanizmu, red. Wit Pasierbek (Kraków: WSFP Ignatianum, WAM, 2008), 51-52.

${ }^{24}$ Podstawy edukacji ignacjańskiej, 113. 
todologii wychowania. Powinna ona kształtować światopogląd i wizję ideału osoby ludzkiej, którą chcemy wychować. Jej właściwością jest nie tylko gromadzenie wiadomości i przygotowanie wychowanka do wykonywania określonego zawodu, ale nade wszystko ,pełny wzrost osoby prowadzący do działania zwłaszcza takiego, które jest przepełnione duchem i obecnością Jezusa Chrystusa, Syna Bożego, Człowieka-dla-Innych". Według V. Duminuco sformułowanie to kreśli oczywiste dążenie do osiągania nakreślonego ideału. Nie jest nim jednak sama doskonałość, osiąganie sukcesów także na drodze niezdrowej konkurencji albo nadmiernego zaangażowania we własne sprawy, lecz rozumienie, co znaczy być ,istotą ludzką” - człowiekiem. Podkreśla, że osiąganie tego ideału jest możliwe na drodze kształtowania osoby zarówno w wymiarze intelektualnym, jak i moralnym. Nie chodzi przy tym o ,sugerowanie programu indoktrynacji, który tłumi ducha; ani o wprowadzanie teoretycznych kursów, które są spekulatywne i odległe od rzeczywistości. Potrzebna jest struktura dociekania dla procesu zmagania się z ważnymi kwestiami i złożonymi wartościami życia”"25. To zaś wymaga wsparcia udzielanego na wszystkich etapach edukacji po to, by wychowanek był w stanie osiągać wysoki poziom dojrzałości. To z kolei domaga się długiego łańcucha zajęć wywołujących konkretne doświadczenia poznawcze, które swym zasięgiem obejmują wszystkie władze duchowe człowieka: rozum, uczucia i wolę ${ }^{26}$. Czynnikiem integrującym w pedagogii ignacjańskiej całokształt tych procesów edukacyjnych jest formacja religijna i duchowa. W formacji tej przywołuje się poza humanistycznymi elementami także personalizm chrześcijański, poznanie religijne oraz życiowe cele człowieka.

Personalizm chrześcijański podkreśla odrębność człowieka wobec innych istnień oraz upatruje $\mathrm{w}$ nim podmiot harmonijnego funkcjonowania w życiu społecznym ${ }^{27}$. Dowartościowanie społecznego wymiaru ludzkiego życia sprzyja eliminowaniu wszystkiego, co prowadzi do skupiania uwagi na sobie oraz ułatwia eksponowanie działań skierowanych na dobro innych ${ }^{28}$.

${ }^{25}$ Vincent J. Duminuco, „Formacja czy indoktrynacja w pedagogice ignacjańskiej?”, w: Pedagogika ignacjańska wobec wyzwań wspótczesnego humanizmu, red. Wit Pasierbek (Kraków: WSFP Ignatianum, WAM, 2008), 175-177.

26 Tamże, 183.

27 Por. Andrzej Zoll, „Człowiek jako podmiot wolności i praw w jednoczącej się Europie”, w: Człowiek w jednoczacej się Europie, red. Anna Królikowska (Kraków: WSFP Ignatianum, WAM, 2004), 45-56.

${ }^{28}$ Por. Jerzy Bagrowicz, „Wychowanie człowieka jako osoby w świetle pedagogiki chrześcijańskiej”, w: Pedagogika chrześcijańska. Tradycja. Współczesność. Nowe wyzwania, red. Jarosław Michalski, Aldona Zakrzewska (Toruń: Wydawnictwo Adam Marszałek, 2010), 
Działania te promują otwartość człowieka na inne osoby, co ułatwia mu samorealizację (osiąganie pełni swego człowieczeństwa) poprzez poszerzanie posiadanej wiedzy, umiejętności właściwego rozsądzania oraz rozwój cnót moralnych, otwierających na wartości kultury ${ }^{29}$. Inną właściwością personalizmu chrześcijańskiego jest objaśnianie natury człowieka w wymiarze teocentrycznym, to znaczy, że Bóg jest ostateczną zasadą ludzkiej egzystencji. Chodzi o podkreślenie, że człowiek całe swe istnienie zawdzięcza Bogu jako Bytowi nieskończonemu, który jest też ostatecznym źródłem i celem każdego innego bytu. Uświadamia to, że człowiek pozostaje w istotnej zależności od Boga.

Kolejnym istotnym dla pedagogii ignacjańskiej elementem jest sposób poznawania rzeczywistości, w jakiej przychodzi człowiekowi żyć. Uczy ona korzystać nie tylko z poznania, którego źródłem jest intelekt - poznanie empiryczne, ale też z poznania, którego źródłem jest Boże objawienie. Tę formę poznania promuje przede wszystkim chrześcijaństwo, stojąc na stanowisku, że przyznanie tylko rozumowi możliwości poznania byłoby zagrożeniem wewnętrznej jedności człowieka. W pierwszym przypadku mówimy o poznaniu intelektualnym - naturalnym, a w drugim o poznaniu religijnym, nazywanym też nadprzyrodzonym. Owa forma poznania wyzwala wprawdzie wiele emocji, nie znaczy to jednak, że nie istnieje. Ta forma poznania wyrasta z przekonania, iż rozum ludzki nie jest w stanie objaśnić wszystkich pytań stawianych przez człowieka. Chrześcijaństwo przyjmuje, że na wiele z nich odpowiedzi udziela człowiekowi Bóg na kartach Biblii. Jego autorytet potwierdza też ich prawdziwośćc ${ }^{30}$.

Podejmując kwestie wzajemnych relacji obu form poznania, podkreślmy, że w żadnym wypadku religia nie wyklucza poznania intelektualnego

48-63; Franciszek Adamski, „Personalistyczna wizja człowieka i kultury u podstaw wychowania chrześcijańskiego", w: Pedagogika chrześcijańska. Tradycja. Współczesność. Nowe wyzwania, red. Jarosław Michalski, Aldona Zakrzewska (Toruń: Wydawnictwo Adam Marszałek, 2010), 64-70; Marian Śnieżyński, Dialog edukacyjny (Kraków: Wydawnictwo Naukowe Papieskiej Akademii Teologicznej, 2001), 45-49; Barbara Kiereś, „Podstawy antropologiczne pedagogiki personalistycznej”, w: Antropologiczna pedagogika ogólna, red. Marian Nowak, Piotr Magier, Iwona Szewczak (Lublin: Wydawnictwo KUL, Gaudium, 2010), 95-102.

${ }_{29}$ Por. Piotr Liszka, „Personalizm”, w: Leksykon pedagogiki religii, red. Cyprian Rogowski (Warszawa: Verbinum, 2007), 571-576; Stanisław Czesław Michałowski, „Pedagogia personalistyczna wsparciem kształtującego się systemu wychowania u początków XXI wieku”, w: Nowe konteksty (dla) edukacji alternatywnej XXI wieku, red. Bogusław Śliwerski (Kraków: Oficyna Wydawnicza „Impuls”, 2001), 643.

30 Jan Paweł II, „Przemówienie do rektorów wyższych uczelni w Polsce ”, L'Osservatore Romano (wyd. pol.) 8 (1999), 29. 
(naturalnego) ${ }^{31}$. Różnica między tymi postaciami poznania polega na tym, że o ile w poznaniu naturalnym człowiek posługuje się naturalną zdolnością poznawczą, jaką jest jego intelekt, to w przypadku poznania religijnego opiera się na wiedzy objawionej - przekazanej przez Boga ${ }^{32}$. Tym samym poznanie religijne, którego źródłem jest nieograniczony Bóg, posiada szersze możliwości od poznania intelektualnego, którego źródłem jest ograniczony rozum. Wartość i znaczenie poznania religijnego polega na tym, że człowiek doświadczający swej ograniczoności uświadamia sobie niemożność wyjaśnienia przy pomocy swego rozumu wszystkich nurtujących go pytań. Chrześcijaństwo podkreśla, że lukę tę wypełnia poznanie religijne. Udziela ono odpowiedzi na pytania dotyczące ludzkiej egzystencji: skąd?, dokąd?, dlaczego? ${ }^{33}$. Wprawdzie poznanie religijne nie jest przez wszystkich akceptowane, ale to nie wyklucza, iż za jego pośrednictwem odwołujemy się do źródeł wykraczających poza ludzki intelekt i że człowiek otrzymuje nowe możliwości poznania, których nie jest w stanie stworzyć poznanie intelektualne (naturalne).

Przedmiot poznania religijnego stanowią objaśnienia spraw, których człowiek nie jest w stanie wytłumaczyć przy pomocy rozumu. Dzięki temu poznaniu człowiek może uzyskiwać odpowiedź na pytania związane z jego egzystencją. Chodzi tu głównie o pytania dotyczące początku życia człowieka i świata, ich przeznaczenia i sensu istnienia ${ }^{34}$. Właśnie ostateczny cel życia człowieka na ziemi stanowi dla pedagogii kolejny istotny element. Cel ten formułuje ona mniej więcej następująco: człowiek przeznaczony (zaproszony) jest przez Boga do życia z Nim przez całą wieczność. Sformułowanie to uświadamia człowiekowi niezbędność podejmowania wysiłku przekraczania siebie, swojej ograniczoności po to, by uczestniczyć w boskim wymiarze człowieczeństwa ${ }^{35}$, którego pełnię odsłania przed ludźmi Jezus Chrystus swoim wkroczeniem w ludzką historię ${ }^{36}$.

${ }^{31}$ Hans Waldenfels, O Bogu, Jezusie Chrystusie i Kościele dzisiaj (Katowice: Księgarnia św. Jacka, 1993), 461.

32 Jan Paweł II, Encyklika Fides et ratio, nr 9 (Watykan, 1998).

33 Por. Stanisław Zięba, „Człowiek. 2. Pochodzenie”, w: Leksykon pedagogiki religii, red. Cyprian Rogowski (Warszawa: Verbinum, 2007), 93-99.

${ }^{34}$ Por. Marek, Religia, $49 \mathrm{n}$.

${ }_{35}$ Paweł Kaźmierczak, Personalistyczna koncepcja wychowania w nauczaniu Jana Pawła II (Kraków: WAM, WSFP Ignatianum, 2003), 23.

${ }^{36}$ Romuald Niparko, „Wychowanie religijne jako wychowanie humanistyczne - perspektywa personalistyczna", Paedagogia Christiana 2 (2003): 19; por. Wojciech Cichosz, 
Powyższe uwagi pokazują, że pedagogii ignacjańskiej nie można uważać za metodologię działań pedagogicznych, dlatego że zmierza ona w kierunku kształtowania zarówno światopoglądu osoby, jak i tworzonej przez nią wizji ideału człowieczeństwa. Promowana wizja człowieka odwołuje się zarówno do wolności, zaufania, miłości, służby, jak też do działania łaski Bożej. W działaniach tych ważną do spełnienia rolę przypisuje się poznaniu religijnemu, które ułatwia rozpoznawanie działania Boga. Doświadczenie to zwiększa poczucie bezpieczeństwa i pewności, że jedynie Bóg jest w stanie doprowadzić człowieka do pełni szczęścia i pełni życia ${ }^{37}$. Droga, na której człowiek dochodzi do tego ideału, promuje zasadę „być człowiekiem dla innych" ${ }^{38}$. W rozumieniu tego postulatu pomocą jest wsparcie w umiejętności korzystania z osiągnięć poznania zarówno intelektualnego, jak i religijnego. Dzięki obu formom poznania łatwiej dochodzi do syntezy antropologii i teologii oraz integrowania w ludzkim życiu wymiaru humanistycznego z wymiarem chrześcijańskim ${ }^{39}$.

\section{Model wychowania inspirowany pedagogią ignacjańską}

W oparciu o założenia pedagogii ignacjańskiej jezuici wypracowali swego rodzaju model wychowania, który można przedstawić w następującym schemacie:

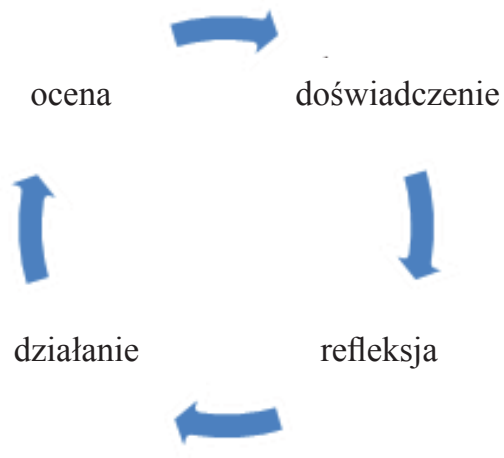

Możliwości dialogu wychowania chrześcijańskiego ze wspótczesna edukacją polska (Pelplin: Bernardinum, 2013), 108-109.

37 Mateo, „Wielkie, 155.

38 Podstawy edukacji ignacjańskiej, 128-129; Duminuco, „Formacja, 75-176.

39 Por. Żmudziński, „Fundament, 53. 
Za podstawę procesu formacji osoby, opartej na założeniach pedagogii ignacjańskiej, przyjmuje się posiadane i gromadzone przez nią doświadczenia. Dzięki ich posiadaniu osoba jest w stanie formułować pytania rodzące się pod wpływem poznania intelektualnego, wyobraźni czy uczuć. Podejmuje się przy tym wysiłki, by nadać im osobowy wymiar po to, by wyzwalały w wychowankach gotowość aktywnego włączania się w procesy formacji i poszukiwania prawdy. Zakłada się, że na tej drodze łatwiej dojdzie do przyswojenia przez nich przekazywanych treści, jak i rozwoju ich osobowości. Działania te nazywa się „,sposobem postępowania”. Służą one rozbudzaniu twórczego myślenia, które sprzyja integralnej formacji osobowości wychowanka ${ }^{40}$.

Przywoływane doświadczenia mają stawać się trampoliną do kolejnych czynności omawianego modelu wychowania. Nazywa się je „refleksją”, która ma wyzwalać chęć „przetwarzania” gromadzonych doświadczeń, a przez to kształtować własny sposób myślenia, własne przekonania, umiejętności i wartościowanie, a także zajmowane w życiu postawy. W czynnościach tych zwraca się uwagę na znaczenie poznania religijnego, które odsłania przed człowiekiem wolę - pragnienie Boga, odnoszącą się do takiego, a nie innego działania człowieka.

W pedagogii ignacjańskiej refleksja stanowi jedno z ważniejszych zadań stawianych przed edukacją. Oczekuje się formułowania zagadnień $\mathrm{w}$ taki sposób, aby wychowankowie mieli możliwość poznania innych punktów postrzegania rzeczywistości. Chodzi zatem o umożliwienie im kształcenia umiejętności postrzegania pojawiającego się problemu z różnych perspektyw. Umiejętność ta rozwija bowiem pragnienie wychodzenia poza sferę własnej ograniczoności ${ }^{41}$. Umiejętność refleksji nad własnymi doświadczeniami sprzyja też kształtowaniu świadomości i przekonań, a także właściwego podejścia do wartości oraz życiowych postaw. Wynika to z umiejętności krytycznego myślenia, którego efektem są działania wynikające $\mathrm{z}$ wolnego wyboru $^{42}$.

W ignacjańskiej tradycji edukacyjnej określenia „,doświadczenie” i „refleksja” oznaczają ,sposób postępowania” w dążeniu do osiągania ,integralnej formacji ucznia". Istotą tej refleksji jest odkrywanie znaczenia doświadczeń dla własnego życia. Chodzi w niej o pochylanie się nad uczuciami wychowanka: pozytywnymi lub negatywnymi, które kształtować będą wolę wy-

\footnotetext{
40 Podstawy edukacji ignacjańskiej, 124-126.

41 Żmudziński, „Fundament, 62.

${ }^{42}$ Duminuco, ,Formacja, 182-185.
} 
chowanka uzdalniającą do wybierania życiowych postaw. Doświadczenia i refleksja są z sobą ściśle powiązane, jako że każda refleksja opiera się na doświadczeniu intelektualnym lub emocjonalnym, intuicji, pewnej jasności czy wizji świata albo jakimś obrazie siebie i innych. Podobnie bez doświadczenia nie można podjąć jakiejkolwiek refleksji.

Oparty na pedagogii ignacjańskiej model formacji osoby zakłada działania wykraczające poza refleksję. Wychodzi się bowiem z założenia, że angażowanie w procesy edukacyjne intelektu i emocji jest niewystarczające. Poza refleksją nad posiadanymi doświadczeniami konieczne jest podjęcie przez wychowanka dojrzałych i odpowiedzialnych decyzji konkretnego działania, jako że tylko one umożliwiają zmianę rzeczywistości, w jakiej żyje. Samo pojęcie „działanie” odnosi się do wewnętrznego wzrostu, rozwoju wychowanka, który podejmuje zagadnienia, które w wyniku przeżytych i przemyślanych doświadczeń mogą prowadzić do konkretnych decyzji. Jest ono powiązane z wyborem własnych priorytetów. Na tym etapie wychowanek zdobytą prawdę zaczyna uważać za swoją własność, ale pozostaje otwarty na to, dokąd ta prawda może go poprowadzić.

Dokonywane wybory w pedagogii ignacjańskiej nazywa się wyborami wewnętrznymi, w odróżnieniu od wyborów zewnętrznych. Wybór taki powiązany jest $\mathrm{z}$ przyjęciem i wewnętrznym zaakceptowaniem poznanych wartości oraz z gotowością do postępowania zgodnego z nowym przekonaniem $^{43}$. Kiedy więc mówimy o działaniu w pedagogii ignacjańskiej, to mamy na myśli wyzwalanie $\mathrm{w}$ wychowanku zdolności podejmowania przez niego działań, które wynikają z nabytych doświadczeń oraz osiągniętego poziomu poznania. Można je przyrównać do ludzkich kompetencji, które służą rozwijaniu dobra wspólnego. W tak rozumianej formacji akcentuje się znaczenie miłości, która w sposób istotny wpływa na postępowanie osoby. Gotowość do takiego postępowania w pedagogii ignacjańskiej wyrażana jest słowem zachęty: magis. Chodzi w nim o dawanie z siebie „więcej” w służbie Bogu i ludziom ${ }^{44}$. Nie podlega przy tym wątpliwościom to, że $w$ takim działaniu wsparciem dla wychowanka jest poznanie religijne, które odsłania przed nim istotę miłości.

Ostatnim elementem opartego na pedagogii ignacjańskiej modelu wychowania jest etap nazwany „oceną”. Czynność ta ma obudzić w wycho-

${ }^{43}$ Podstawy edukacji ignacjańskiej, 127-128.

${ }^{44}$ Duminuco, „Formacja, 185; por. Janusz Mółka, Bogusław Steczek, „Magis jezuickiej edukacji”, w: Pedagogika ignacjańska wobec wyzwań współczesnego humanizmu, red. Wit Pasierbek (Kraków: WSFP Ignatianum, WAM, 2008), 227-245. 
wanku umiejętność dokonywania właściwej oceny swych osiągnięć. Chodzi głównie o dostrzeganie efektów wzrostu intelektualnego, jak i ludzkiego wewnętrznego, który stwarza podstawę osiągania dojrzałości. Zdolność oceny ma sprzyjać integralnemu rozwojowi osoby jako „osoby dla drugich”. Podstawą takich postaw jest zaufanie i szacunek łączący wychowawców i wychowanków oraz zaufanie do Boga. Bodźców do takich działań dostarcza zarówno personalizm chrześcijański, jak i poznanie religijne.

Duchowość stanowiącą podstawy pedagogii ignacjańskiej Bogusław Steczek nazywa duchowością umiaru. Chce w ten sposób podkreślić, że wyklucza ona fanatyzm na rzecz nabywania umiejętności maksymalizmu, który wyraża słowo magis. „Uczy spokojnego, mądrego spojrzenia na rzeczywistość, nawet najtrudniejszą, bo wyrasta z przekonania, że wszystko jest w ręku Boga", czym promuje postawę wyrozumienia, współczucia, cierpliwości, miłosierdzia, a także wszelkiego rodzaju angażowania się na rzecz pojednania i wprowadzania pokoju ${ }^{45}$.

\section{Ignacy i pierwsi towarzysze ludźmi przebaczenia, dialogu i pojednania}

Przywołując przedłożone elementy duchowości ignacjańskiej i zbudowane na niej zasady pedagogii, podejmiemy próbę opisu procesu formacji do przebaczenia i pojednania. Przy jego opisie należy najpierw zwrócić uwagę na to, że kwestia przebaczenia i pojednania była aktualna dla samego Ignacego oraz jego pierwszych towarzyszy. Najpierw zauważmy, że święty Ignacy w swoich tekstach: Ćwiczenia duchowne ${ }^{46}$, Dziennik duchowy ${ }^{47}$ oraz Konstytucje $^{48}$, gdy mówi o przebaczeniu, używa słów: perdon, perdonar. Terminy te odnoszą się przede wszystkim do relacji człowieka z Bogiem. Mniej odwołują się do relacji międzyosobowych, gdyż bardziej podkreślają przebaczenie otrzymywane od Boga niż od ludzi ${ }^{49}$. Podobny sens mają

45 Por. Steczek, „Charakterystyczne, 84.

${ }^{46}$ Ignacy Loyola, Ćwiczenia duchowne (Kraków: Wydawnictwo WAM, 2002) - w tekście ĆD z odnośnym numerem.

47 Ignacy Loyola, Pisma Wybrane, t. 1, oprac. Mieczysław Bednarz (Kraków: Wydawnictwo WAM, 1968), 275-389.

${ }^{48}$ Konstytucje Towarzystwa Jezusowego (Kraków: Wydawnictwo WAM, 2001) - w tekście Konst. z odnośnym numerem.

49 Ignacio Echarte, Concordancia ignaciana (Bilbao-Santander: Ediciones MensajeroSal Terrae, 1996), 885, 945-946, 1089. 
inne określenia występujące w tych samych tekstach: reconciliacion, które oznacza pojednanie; reconciliar, które wyraża jednać; pacifcar, które znaczy wprowadzać pokój, godzić. Także i one, chociaż używane są do wyrażenia pojednania między ludźmi, częściej odnoszą się do pojednania człowieka z Bogiem, Trójcą Świętą, Jezusem Chrystusem. Zostaje przy tym podkreślone, że jeśli pojednanie z Bogiem jest autentyczne, to zawsze będzie ono prowadzić człowieka do doświadczenia wewnętrznego pokoju. Dla Ignacego oparte na przebaczeniu pojednanie $\mathrm{z}$ Bogiem zawsze jest pierwszym i najważniejszym doświadczeniem. Jedność z Bogiem prowadzi do przebaczenia, a następnie pojednania z ludźmi. Tych dwóch rzeczywistości nie można od siebie rozdzielać. One w duchowości ignacjańskiej wzajemnie się uzupełniają i wyjaśniają ${ }^{50}$.

Święty Ignacy i pierwsi towarzysze w dokumentach fundacyjnych, zwłaszcza w Formule Instytutu i Konstytucjach, sformułowali istotne elementy charyzmatu Towarzystwa Jezusowego. Znajdują się w nich także elementy mówiące o przebaczeniu, pojednaniu i dialogu. Formuła Instytutu ${ }^{51}$ z 1550 roku, która jest podstawowym dokumentem prawnym, określającym zasady istnienia i funkcjonowania Towarzystwa Jezusowego ${ }^{52}$, stwierdza, że do istoty powołania Towarzystwa, oprócz sprawowania sakramentów i głoszenia Słowa Bożego, należy także spełnianie „uczynków miłosierdzia”, pośród których na pierwszym miejscu podaje „,pojednanie zwaśnionych”. Ojciec Hieronim Nadal, komentując ten punkt Formuly Instytutu, stwierdza, że spełniając tę posługę jezuici realizują błogosławieństwa ewangeliczne. W niej zawarte są wszystkie błogosławieństwa ${ }^{53}$.

Pojednanie jest misją specjalnie zleconą Towarzystwu Jezusowemu. Ma ono uczestniczyć i pomagać w dialogu i pojednaniu między ludźmi. Towarzystwo zawsze formowało w tym duchu swoich członków, dążąc, by byli ludźmi słowa, dialogu, pokoju i pojednania. Od samego początku istnienia starało się ,jednać zwaśnionych", traktując tę posługę jako ważny aposto-

50 Jose Carlos Coupeau, „Reconciliacion”, w: Diccionario de espiritualoidad ignaciana, t. 2, red. Jose Garcia de Castro (Bilbao-Santander: Ediciones Mensajero-Sal Terrae, 2007), 1534; Jose Carlos Coupeau, „Pacificar”, w: Diccionario de espiritualoidad ignaciana, t. 2, red. Jose Garcia de Castro (Bilbao-Santander: Ediciones Mensajero-Sal Terrae, 2007), 1391-1399.

51 Konstytucje Towarzystwa Jezusowego (Kraków: Wydawnictwo WAM, 2001), 29-39.

52 Jakub Kołacz, Słownik języka i kultury jezuitów polskich (Kraków: Wydawnictwo WAM, 2006), 115.

${ }^{53}$ Coupeau, ,Reconciliacion”, 1535. 
lat ${ }^{54}$. Ten sam duch Ćwiczeń i Formuły jest widoczny w Konstytucjach Towarzystwa Jezusowego. Jezuici mają się oddawać nie tylko posługom duchowym, ale także uczynkom miłosierdzia co do ciała. Jednym z nich jest godzenie zwaśnionych (Konst. 650). Kandydat do życia w zakonie powinien posiadać odpowiedni dar wymowy i słowa, by skuteczniej pomagać bliźnim (Konst. 157). Jezuici w swoim posługiwaniu mają spotykać się z przeróżnymi ludźmi i powinni używać wszystkich możliwych środków, by móc lepiej służyć Bogu i ludziom (Konst. 414). W innym miejscu Konstytucji czytamy, że sposób działania i postępowania jezuitów z ludźmi jest ważny. Od niego bowiem zależy rozwój zakonu i skuteczność posługiwania ludziom (Konst. 814).

Święty Ignacy w jednym z listów pisze, że prowadzenie rozmów z innymi należy do istoty powołania jezuity. Przekonanie to zamknął w Konstytucjach podkreśleniem, że jezuici mają wspierać bliźnich poprzez prywatne rozmowy, pobudzając ich do tego co lepsze (Konst. 649). Bycie człowiekiem słowa nie oznacza wielości słów, ale umiar w mówieniu i umiejętność uważnego słuchania. Ojcom udającym się na Sobór Trydencki (Faber, Laynez, Salmeron) polecał mówić rozważnie i z miłością dla słuchacza. Powinni słuchać z uwagą, wczuwając się w to, co mówi i przeżywa interlokutor. Pośród pierwszych jezuitów mistrzem tak rozumianego dialogu był św. Piotr Faber. Umiejętnie i skutecznie prowadził go z protestantami w Niemczech. W jednym $\mathrm{z}$ listów pisał, że w dialogu z nimi najważniejsza jest prawdziwa miłość i szacunek do nich.

Dialog i pojednanie w życiu Ignacego oraz Towarzystwa wypływają $\mathrm{z}$ głębokiego przekonania i wiary w obecność Boga w drugim człowieku, z którym jest się zwaśnionym, poróżnionym lub prowadzi rozmowę ${ }^{55}$. Ignacy i pierwsi jego towarzysze byli mediatorami w wielu konfliktach. Doprowadzenie do pojednania było często początkiem i warunkiem pojednania z Bogiem. W pierwotnych sprawozdaniach z działalności jezuitów często jest mowa o różnych sytuacjach godzenia zwaśnionych stron. Ten typ działań znany jest pod pojęciem hacer paces - wprowadzać pokój, jednać, godzić $^{56}$. W praktyce termin ten nie był też obcy Ignacemu, który po swym

54 John W. O’Malley, Pierwsi jezuici (Kraków: Wydawnictwo WAM, 2007), 243-244; Mark Rotsaert, „Una spiritualita’ del dialogo e della riconciliazione”, Ignaziana 15 (2013): $36-37$.

55 O’Malley, Pierwsi, 243-244; Rotsaert, „Una spiritualita', 36-37.

56 Íñigo Arranz, „Pacificar y reconciliar desavenidos en la primitiva Compania”, Manresa 77, 1 (2005): 151 . 
nawróceniu, ale jeszcze przed założeniem zakonu, powrócił w rodzinne strony, by pomóc rozwiązać wieloletni konflikt między klerem parafialnym i zakonnicami, tak zwanymi „Izabelitkami”, w który były też zaangażowane zwaśnione rody Loyola i Anchieta. Misja ta zakończyła się sukcesem ${ }^{57}$.

Ignacy od samego początku związania się z ,pierwszymi towarzyszami” (tak nazywali się ci, którzy z czasem dali początek zakonowi jezuitów) starał się o ich jedność opartą na przebaczeniu. Poświęcił wiele czasu i szczególnie dużo serca włożył w pojednanie z trudnym współbratem Szymonem Rodriguezem, który pisał o sobie: „chociaż jestem złym synem, to jednak jestem jego synem". Ignacy nigdy się na niego nie zamknął. Traktował go po ojcowsku przez okazywanie mu cierpliwości, miłości i przebaczenia po to, by zachować z nim jedność i pokój ${ }^{58}$. Tę troskę dostrzegł też inny jezuita, O. Jeronimo Domenech, który - pisząc o życiu i działalności świętego Ignacego jako generała zakonu w Rzymie i wymieniając różne jego zajęcia zauważył, że Magister Ignacy dużo czasu i miejsca w swoim posługiwaniu poświęcał tratar ciertas paces de mucha importancia - zajmował się sprawami wprowadzania pokoju o wielkim znaczeniu ${ }^{59}$.

Misję ,jednania zwaśnionych” pełnił święty Ignacy także będąc generałem zakonu poprzez zaangażowanie w łagodzenie konfliktów zagrażających jedności rodzin, Kościoła i krajów. Tak było w przypadku doprowadzenia do pojednania dwóch wielkich przyjaciół i dobroczyńców zakonu: króla Portugalii Jana III i papieża Pawła III. Powodem konfliktu między nimi było mianowanie kardynałem przez papieża, wbrew królowi, Michała da Silvę ${ }^{60}$. Ignacy jako generał zakonu zaangażował się też i w to, by zapobiec rozbiciu małżeństwa księcia Ascanio Colonna i Joanny Aragońskiej. W tym celu osobiście udał się z Rzymu w okolice Neapolu na spotkanie z księżniczką. Napisał do niej długi list, ukazując konieczność przebaczenia i zachęcając do powrotu do opuszczonego przez nią męża i pojednania z nim. Także i tym razem jego mediacja była skuteczna ${ }^{61}$. W liście do Joanny Aragońskiej napisał między innymi, że nie można osiągnąć pokoju i pojednania bez wzajemne-

${ }^{57}$ Cándido de Dalmases, Człowiek, który widzial wszystko (Kraków: Wydawnictwo WAM, 1989), 136-138; Rotsaert, „Una spiritualita’, 39.

${ }^{58}$ Coupeau, ,Reconciliacion”, 1535.

59 Santiago Thio, „Ignacio: de la humildad a la pacificacion”, Manresa 77, 1 (2005): 125.

${ }^{60}$ Rotsaert, „Una spiritualita', 39-40.

${ }^{61}$ Tamże, 40-43; Coupeau, ,Reconciliacion”, 1535. 
go przebaczenia, ukorzenia się, zrezygnowania z urazów i zapomnienia ran wzajemnie sobie zadanych ${ }^{62}$.

Dokumenty opisujące działalność pierwszych jezuitów często wspominają o pełnieniu przez nich misji ,godzenia zwaśnionych” stron. Misja hacer paces należała do istotnych $\mathrm{w}$ ich posługiwaniu. Oto niektóre $\mathrm{z}$ licznych przykładów. Pierwsi jezuici prowadzili misję doktrynalnego pojednania zwaśnionych stron. Tak było przy podejmowaniu prób godzenia katolików z protestantami w Anglii, Irlandii, Niemczech i Francji. Sukcesem pojednania zakończyła się misja C. Jay, który swoim stylem i przykładem życia przyczynił się do pojednania poróżnionych mieszkańców w Faenza i Bagnorea. Swoimi kazaniami przekonał ich do zaniechania krwawych walk, które wydarzały się od wielu lat. Podobnie P. Broet pomagał pojednać się poróżnionym rodzinom na północy Włoch - Romagna. W Faenzy zaś zorganizował liturgię pojednania, podczas której mieszkańcy wybaczyli sobie zabójstwa, krzywdy i nienawiści. Z kolei A. Araoz pogodził poróżnionych małżonków - księcia i księżną Kalabrii. J. Laynez w Monreale pogodził zakonników z lokalnym klerem. Natomiast w Ingolstadt jezuici pomogli pojednać się poróżnionym profesorom $\mathrm{z}$ uniwersytetu, wśród których panowała wielka nienawiść. F. Estrada w Montepulciano przyczynił się swoimi kazaniami do pojednania rodzin wrogo do siebie nastawionych po zabójstwie ich członków. Podobnym sukcesem zakończyła się misja S. Landiniego, który swymi kazaniami i pouczeniami godził mieszkańców Correggio oraz okolic Modeny, wśród których miało miejsce wiele wzajemnych morderstw, rabunków i kradzieży ${ }^{63}$. To tylko niektóre z przykładów życia i działalności świętego Ignacego i pierwszych jego towarzyszy, które ukazują, jak poza głoszeniem Słowa Bożego i sprawowaniem sakramentów - ważne było w ich codziennym posługiwaniu pełnienie uczynków miłosierdzia, zwłaszcza ,jednanie zwaśnionych". Jezuici nie tylko sami tę posługę spełniali, ale formowali innych do jej pełnienia.

\section{4. Ćwiczenia duchowne podstawowym doświadczeniem przebaczenia i pojednania}

Chęć i gotowość do podejmowania działań na rzecz pojednania i przebaczenia wpisana jest w duchowość ignacjańską. W szczególny sposób do-

${ }^{62}$ Rotsaert, „Una spiritualita’, 41.

${ }^{63}$ Arranz, „Pacificar, 140-144; O’Malley, Pierwsi, 243-246. 
świadczają jej biorący udział w ćwiczeniach duchownych nazywanych też rekolekcjami. Doświadczenia te stają się udziałem rekolektanta przede wszystkim podczas rozważań pierwszego tygodnia odprawianych ćwiczeń. $\mathrm{W}$ tym czasie spotyka się on nie tylko $\mathrm{z}$ własnym grzechem, ale z miłosierną miłością Boga, który mu przebacza grzech i jedna z Sobą. To doświadczenie ma pomóc $\mathrm{w}$ osiągnięciu nowego i głębszego poznania siebie jako grzesznika. Dlatego rekolektant ma patrzeć na siebie i swoje życie tak, aby odkrywać w nim obecność grzechu. Spotkanie z Jezusem ukrzyżowanym pozwala mu oderwać się od drogi grzechu i wybrać drogę zbawienia i wolności. Z Ukrzyżowanym i Jego oczami uczy się patrzeć na swoją przeszłość, teraźniejszość i przyszłość (ĆD 53). Jego efektem ma być otwarcie się na nową relację z Jezusem Chrystusem. Spotkanie to wyzwala człowieka z grzechu i przeświadczenia o samowystarczalności. Rodzi nowe otwarcie na siebie samego i ułatwia pojednanie się z sobą samym. Rekolektant, jednocząc się z Bogiem i sobą samym, nabywa nową i bardziej realistyczną wizję siebie samego. Ma to wpływ nie tylko na jego relacje z Bogiem, ale też rodzi w nim nową postawę wobec innych - postawę przebaczenia i pojednania ${ }^{64}$. Dzięki doświadczeniu Boga, który zbawia człowieka i okazuje mu swoje miłosierdzie, ćwiczenia duchowne pomagają stać się wolnym w relacji z innymi i dla innych. Doświadczone przebaczenie prowadzi do postawy otwarcia, spotkania i dialogu. Dialog z Bogiem otwiera na dialog z innymi. Osoby uformowane przez ćwiczenia powinny być ludźmi słowa, dialogu i spotkania ${ }^{65}$.

Można oczekiwać, że rekolektant zaczyna rozumieć, że chociaż na to nie zasłużył, jest przez Boga kochany i pojednany z Nim i sobą samym. Od tego też momentu wchodzi na drogę pokoju, dzieląc się tym, co darmo otrzymał: darmową miłość miłosierną i przebaczenie. Pragnąc naśladować miłosiernego Jezusa, uczy się rozumieć, na czym polega przebaczenie i pojednanie. Myślenie to budzi w nim również pytanie, co powinien dla Jezusa uczynić (ĆD 53). Następstwem takich działań jest człowiek uformowany duchowością ćwiczeń. Ona powoduje, że staje się dobrym duchem, aniołem pokoju, który niesie innym wewnętrzny pokój przez przebaczanie i godzenie poróżnionych czy zwaśnionych ${ }^{66}$.

${ }^{64}$ Luis M. Garcia Dominguez, „La reconciliacion consigo mismo en la primera semana de los Ejercicios", Manresa 79 (2007), 38-41; Javier Melloni, La mistagogia de los Ejercicios (Bilbao-Santander: Ediciones Mensajero-Sal Terrae, 2001), 131-135, 159-160; Carlos Dominguez Morano, „Los Ejercicios Espirituales, experiencia de reconciliacion”, Manresa 77, 1 (2005): 110-112.
${ }^{65}$ Rotsaert, „Una spiritualita', 34-35.
${ }^{66}$ Coupeau, „Reconciliacion”, 1396. 
Kluczowy tekst, tak zwane praesupponendum, który leży u podstaw przebaczenia, dialogu i pojednania, domaga się: „każdy dobry chrześcijanin winien być bardziej skory do ocalenia wypowiedzi bliźniego niż do jej potępienia" (ĆD 22). Należy w nim doszukiwać się podstaw wszelkiego dialogu, który zakłada wzajemne zaufanie i otwartość na człowieka. Ufność, pozytywne nastawienie „dobrego chrześcijanina” nie oznacza bycia bezkrytycznym, uległym wobec innych, pozwalając im narzucić swoje przekonania i poglądy. Miłość do prawdy, szacunek i ufność wobec drugiego stanowią założenia niezbędne, bo pomagają i uzdalniają do właściwego zrozumienia innych. Zaufanie drugiemu człowiekowi pozwala dostrzec jego problemy i właściwie je ocenić oraz prowadzić do przebaczenia, jak również pojednania z ludźmi ${ }^{67}$. Należy też zwrócić uwagę i na to, że praesupponendum mówi nie tylko o dialogu pomiędzy osobami, ale o nawiązywaniu dialogu z Bogiem. Ufność, szczerość i otwartość są warunkiem spotkania z Bogiem. Dialog z Nim zmienia rekolektanta i czyni go „dobrym chrześcijaninem”, którym Bóg chce się posłużyć w przekazywaniu innym swojej miłości, przebaczenia i pojednania. Podziały i waśnie między ludźmi mają często u podstaw nieumiejętność słuchania nie tylko ludzi, ale przede wszystkim Boga.

W końcu zwróćmy uwagę na jeszcze jeden znaczący dla rozważanego problemu wątek umieszczony przez Ignacego w książeczce Ćwiczeń duchownych. Na jej końcu umieszcza „Reguły o trzymaniu z Kościołem” (ĆD 352-370). Ich zadaniem jest ukonkretnienie praesupponendum w życiu Kościoła. Rekolektant pojednany z Bogiem, rozkochany w Chrystusie, zostaje zaproszony do przyjęcia właściwej postawy wobec Kościoła nie tylko jego czasów. Reguły te podejmują trudne sytuacje i problemy teologiczne. Bezpośrednio nawiązują do problemów, które istniały w XVI wieku i odnosiły się do ówczesnych zwyczajów i tradycji, spraw doktrynalnych, jak problem łaski i wolność człowieka czy predestynacja itp. Sprawy te nie tylko dzieliły ludzi Kościoła, ale też wrogo nastawiały ich do siebie. Celem tych reguł jest troska o jedność ludzi Kościoła, a ich stosowanie ma przeciwdziałać wszystkiemu, co niszczy komunię Kościoła. Dlatego Ignacy zachęca w nich do kierowania się wiarą wobec nauczania Kościoła. Równocześnie stwierdza, że postawę, jaką winno się przyjąć wobec tradycyjnych zwyczajów, ma charakteryzować pochwała. Natomiast w kwestiach różnic teologicznych Ignacy proponuje postawę pastoralną: „trzeba być roztropnym w sposobie

67 Toni Witwer, „Testi ignaziani per il dialogo e la riconciliazione: Esercizi spirituali, Costituzioni, Lettere", Ignaziana 15 (2013): 48-51. 
mówienia i rozprawiania o tych wszystkich sprawach" (ĆD 366) ${ }^{6}$. Reguły te nic nie tracą ze swojej aktualności także i dzisiaj, zwłaszcza w sytuacji różnych napięć, problemów i różnic istniejących wśród ludzi Kościoła. Trzeba nam zawsze bardziej ocalać wypowiedź bliźniego niż ją potępiać.

Powyższe przedłożenie nie formułuje zasad promowanego w pedagogii ignacjańskiej modelu edukacji do przebaczenia. Bez większego błędu możemy też powiedzieć, że modelu takiego nie są też w stanie zaproponować inne pedagogie $\mathrm{z}$ prostego powodu: przebaczenie, pojednanie są działaniami wolnego człowieka. Można więc jedynie stwarzać osobie możliwości do wypracowywania własnego narzędzia, które będzie pomocne w realnym okazywaniu przebaczenia. Pedagogia ignacjańska, która wyrosła z ducha ćwiczeń duchownych, promuje wpatrywanie się we wszystko to, czego człowiek doświadcza od Boga. Bezinteresowna miłość okazana w przyjściu na świat Jezusa Chrystusa i posunięta do ofiary życia na krzyżu oraz ofiarowane człowiekowi przez Zmartwychwstałego życie wieczne stanowią inspirację i punkt odniesienia do podejmowania działań związanych z przebaczeniem. W kwestii tej, jak się wydaje, ważną rolę pełni też troska o duchowy rozwój osoby, w którym ważną rolę pełnią relacje z Bogiem. Ich waga polega na tym, że dostarczają człowiekowi właściwego rozeznania o wartości i sensie ludzkiego życia, a nadto dostarczają nowych motywów takiego, a nie innego działania. Tym samym można mówić, że do istoty edukacji do przebaczenia w pedagogii ignacjańskiej należy rozwijanie duchowości, dzięki której wychowanek będzie nabywał umiejętność przyjmowania określonych postaw, rozumienia tradycji, w jakich przychodzi mu się rozwijać oraz kierowania się konkretnymi wartościami. Dodajmy, że dla pedagogii ignacjańskiej zakresy takiego funkcjonowania osoby wspierane są przez religię odsłaniającą człowiekowi pełny sens jego życia.

${ }^{68}$ Por. Rotsaert, „Una spiritualita’, 38; Por. Pep Buades, „Y tambien manifiestese preparado para reconciliar desavenidos... entre turcos o cualesquiera otros infieles”, Manresa 77 (2005), 169-178. 


\section{Forgiveness Education in the Ignatian Pedagogy (Summary)}

The authors of the article explain how the Ignatian pedagogy supports the students in solving problems related to forgiveness and reconciliation. They point out that it does not provide rules leading automatically to the reconciliation of the feuding parties. Instead, one might speak of the process, which is contingent on a variety of human circumstances. The authors indicate that the Ignatian spirituality understood as a manner of human conduct can help the person understand the nature and basis of forgiveness. The source of this support, which is also called the formation of man, is the Christian faith, and the method of transmitting it is a spiritual retreat. In the course of the retreat, the person realizes the truth about himself and about what God has done for him. The gradual weighing of both of these realities leads the person to recognize the disproportion between the forgiveness received and the one expected of him/her. The Ignatian pedagogy taps into this line of thinking and acting. It is about providing the student with the conditions to understand the meaning of forgiveness and triggering the readiness for such action. This kind of reflection is coupled with religious knowledge, which, apart from natural cognition, is an important point of reference for the Ignatian pedagogy.

Key words: Ignatian pedagogy; spirituality; Ignatian spirituality; spiritual exercises; formation; Ignatius of Loyola.

\section{Edukacja do przebaczenia w pedagogii ignacjańskiej (Streszczenie)}

Autorzy artykułu wyjaśniają, jak pedagogia ignacjańska wspiera wychowanków w rozwiązywaniu problemów związanych z przebaczeniem i pojednaniem. Tłumaczą, że w świetle jej założeń nie można mówić o regułach, których zastosowanie niemal mechanicznie doprowadzi do pojednania zwaśnionych stron. Wskazują, że w tym przypadku należy mówić o procesie, który związany jest z różnymi okolicznościami człowieka. Opierając się na duchowości ignacjańskiej, którą rozumieją jako sposób czy też styl postępowania człowieka, wskazują, że za jej pośrednictwem można wesprzeć osobę w zrozumieniu istoty i podstaw przebaczenia. Źródłem tak rozumianego wsparcia, nazywanego też formacją człowieka, jest wiara chrześcijańska, natomiast metodą - ćwiczenia duchowne (rekolekcje). Proces, jaki następuje w ich toku, uświadamia człowiekowi prawdę o nim samym, a także o tym, co dla 
niego uczynił Bóg. Stopniowe ważenie obu tych rzeczywistości prowadzi osobę do uznania nieproporcjonalnego daru przebaczenia, jaki staje się jego udziałem wobec tego, jakiego winien udzielić. Do tego toku myślenia i działania człowieka odwołuje się pedagogia ignacjańska. Chodzi w niej o tworzenie wychowankowi warunków do zrozumienia sensu przebaczenia i wyzwalania w nim gotowości takiego działania. W tego rodzaju refleksję wprzęgnięte zostaje poznanie religijne, które obok poznania naturalnego jest ważnym punktem odniesienia dla pedagogii ignacjańskiej.

Słowa kluczowe: pedagogia ignacjańska; duchowość; duchowość ignacjańska; ćwiczenia duchowne; formacja; Ignacy Loyola.

\section{Bibliografia}

Adamski, Franciszek. „Personalistyczna wizja człowieka i kultury u podstaw wychowania chrześcijańskiego". W: Pedagogika chrześcijańska. Tradycja. Współczesność. Nowe wyzwania, red. Jarosław Michalski, Aldona Zakrzewska, 64-70. Torun: Wydawnictwo Adam Marszałek, 2010.

Arranz, Íñigo. „Pacificar y reconciliar desavenidos en la primitiva Compania”. Manresa 77, 1 (2005): 139-152.

Augustyn, Józef. „Ćwiczenia duchowne jako podstawa pedagogiki ignacjańskiej”. W: Pedagogika ignacjańska. Historia, teoria, praktyka, red. Anna Królikowska, 13-22. Kraków: WSFP Ignatianum, WAM, 2010.

Bagrowicz, Jerzy. „Wychowanie człowieka jako osoby w świetle pedagogiki chrześcijańskiej". W: Pedagogika chrześcijańska. Tradycja. Współczesność. Nowe wyzwania, red. Jarosław Michalski, Aldona Zakrzewska, 48-63. Toruń: Wydawnictwo Adam Marszałek, 2010.

Buades, Pep. ,Y tambien manifiestese preparado para reconciliar desavenidos... entre turcos o cualesquiera otros infieles". Manresa 77, 1 (2005): 169-178.

Chlewiński, Zdzisław. „Formacja”. W: Encyklopedia katolicka, t. V, 389. Lublin: TN KUL, 2004.

Chmielewski, Marek. „Duchowość”. W: Leksykon duchowości katolickiej, red. Marek Chmielewski, 226-232. Lublin-Kraków: Wydawnictwo „M”, 2002.

Cichosz, Wojciech. Możliwości dialogu wychowania chrześcijańskiego ze współczesna edukacją polską. Pelplin: Bernardinum, 2013.

Coupeau, Jose Carlos. „Pacificar”. W: Diccionario de espiritualoidad ignaciana, t. 2, red. Jose Garcia de Castro, 1391-1399. Bilbao-Santander: Ediciones Mensajero-Sal Terrae, 2007. 
Coupeau, Jose Carlos. „Reconciliacion”. W: Diccionario de espiritualoidad ignaciana, t. 2, red. Jose Garcia de Castro, 1534-1538. Bilbao-Santander: Ediciones Mensajero-Sal Terrae, 2007.

Dalmases, Cándido de. Człowiek, który widział wszystko. Kraków: Wydawnictwo WAM, 1989.

Dominguez Morano, Carlos. „Los Ejercicios Espirituales, experiencia de reconciliacion”. Manresa 77, 1 (2005): 109-123.

Duminuco, Vincent J. „Formacja czy indoktrynacja w pedagogice ignacjańskiej?”. W: Pedagogika ignacjańska wobec wyzwań współczesnego humanizmu, red. Wit Pasierbek, 173-192. Kraków: WSFP Ignatianum, WAM, 2008.

Echarte, Ignacio. Concordancia ignaciana. Bilbao-Santander: Ediciones Mensajero-Sal Terrae, 1996.

Fleming, Dawid L. Czym jest duchowość ignacjańska? Kraków: WAM, 2013.

Gałdowa, Anna, Aleksander Nelicki. „O możliwościach i warunkach bycia twórczym z perspektywy aksjologicznej teorii wartości”. Zeszyty Naukowe Uniwersytetu Jagiellońskiego. Prace Psychologiczne 8 (1993): 7-28.

Garcia Dominguez, Luis M. „La reconciliacion consigo mismo en la primera semana de los Ejercicios". Manresa 79 (2007): 37-51.

Gutek, Gerald L. Filozoficzne i ideologiczne podstawy edukacji. Gdańsk: Gdańskie Wydawnictwo Psychologiczne, 2003.

Jan Paweł II. „Przemówienie do rektorów wyższych uczelni w Polsce”. L’Osservatore Romano (wyd. pol.) 8 (1999): 29.

Jan Paweł II. Encyklika Fides et ratio. Watykan, 1998.

Kaźmierczak, Paweł. Personalistyczna koncepcja wychowania w nauczaniu Jana Pawła II. Kraków: WAM, WSFP Ignatianum, 2003.

Kiereś, Barbara. „Podstawy antropologiczne pedagogiki personalistycznej”. W: Antropologiczna pedagogika ogólna, red. Marian Nowak, Piotr Magier, Iwona Szewczak, 95-102. Lublin: Wydawnictwo KUL, Gaudium, 2010.

Kołacz, Jakub. Słownik języka i kultury jezuitów polskich. Kraków: Wydawnictwo WAM, 2006.

Konstytucje Towarzystwa Jezusowego. Kraków: Wydawnictwo WAM, 2001.

Ladaria, Luis F. Wprowadzenie do antropologii teologicznej. Kraków: WAM, 2002.

Liszka, Piotr. „Personalizm”. W: Leksykon pedagogiki religii, red. Cyprian Rogowski, 571-576. Warszawa: Verbinum, 2007.

Loyola, Ignacy. Pisma Wybrane, t. 1, oprac. Mieczysław Bednarz. Kraków: Wydawnictwo WAM, 1968.

Marek, Zbigniew. Religia - pomoc czy zagrożenie dla edukacji? Kraków: WAM, 2014. 
Marszalek, Lidia. Duchowość dziecka. Znaczenia * Perspektywy * Konteksty w pedagogice przedszkolnej. Warszawa: Mazowieckie Centrum Poligrafii, 2013.

Mateo, Rogelio García. „Wielkie pragnienia i ideały człowieka według św. Ignacego Loyoli. U podstaw pedagogii magis". W: Pedagogika ignacjańska wobec wyzwań wspótczesnego humanizmu, red. Wit Pasierbek, 139-156. Kraków: WSFP Ignatianum, WAM, 2008.

Melloni, Javier. La mistagogia de los Ejercicios. Bilbao-Santander: Ediciones Mensajero-Sal Terrae, 2001.

Michalski, Jarosław. Edukacja i religia jako źródło rozwoju egzystencjalno-kognitywnego. Studium hermeneutyczno-krytyczne. Toruń: UMK, 2004.

Michałowski, Stanisław Czesław. „Pedagogia personalistyczna wsparciem kształtującego się systemu wychowania u początków XXI wieku". W: Nowe konteksty (dla) edukacji alternatywnej XXI wieku, red. Bogusław Śliwerski, 643. Kraków: Oficyna Wydawnicza „Impuls”, 2001.

Milerski Bogusław. Religia a szkoła. Status edukacji religijnej w szkole w ujęciu ewangelickim. Warszawa: Chrześcijańska Akademia Teologiczna, 1998.

Mółka, Janusz, Bogusław Steczek. „Magis jezuickiej edukacji”. W: Pedagogika ignacjańska wobec wyzwań wspótczesnego humanizmu, red. Wit Pasierbek, 227-250. Kraków: WSFP Ignatianum, WAM, 2008.

Niparko, Romuald. „Wychowanie religijne jako wychowanie humanistyczne - perspektywa personalistyczna". Paedagogia Christiana 2 (2003): 9-22.

Nowak, Marian. Pedagogiczny profil nauk o wychowaniu. Lublin, Wydawnictwo KUL, 2012.

O’Malley, John W. Pierwsi jezuici. Kraków: Wydawnictwo WAM, 2007.

Podstawy edukacji ignacjańskiej, thum. Bogusław Steczek. Kraków: WSFP Ignatianum, WAM, 2006.

Rotsaert, Mark. „Una spiritualita' del dialogo e della riconciliazione”. Ignaziana 15 (2013): 33-45.

Rubacha, Krzysztof. „Edukacja jako przedmiot pedagogiki i jej subdyscyplin”. W: Pedagogika. Podręcznik akademicki, t. 1, red. Zbigniew Kwieciński, Bogusław Śliwerski, 21-33. Warszawa: PWN, 2005.

Steczek, Bogusław. „Charakterystyczne rysy duchowości ignacjańskiej - inspiracja dla rozwoju człowieka". W: Pedagogika wiary, red. Andrzej Hajduk, Janusz Mółka, 73-84. Kraków: WSFP Ignatianum, WAM, 2007.

Śnieżyński, Marian. Dialog edukacyjny. Kraków: Wydawnictwo Naukowe Papieskiej Akademii Teologicznej, 2001.

Thio, Santiago. „Ignacio: de la humildad a la pacificacion”. Manresa 77, 1 (2005): 125-137. 
Waldenfels, Hans. O Bogu, Jezusie Chrystusie i Kościele dzisiaj. Katowice: Księgarnia św. Jacka, 1993.

Witwer, Toni. „Testi ignaziani per il dialogo e la riconciliazione: Esercizi spirituali, Costituzioni, Lettere". Ignaziana 15 (2013): 46-55.

Wójtowicz, Marek. „Dynamika Ćwiczeń duchownych św. Ignacego Loyoli w ujęciu Gillesa Cussona". W: Pedagogika ignacjańska. Historia, teoria, praktyka, red. Anna Królikowska, 57-84. Kraków: WSFP Ignatianum, WAM, 2010.

Zięba, Stanisław. „Człowiek. 2. Pochodzenie”. W: Leksykon pedagogiki religii, red. Cyprian Rogowski, 93-99. Warszawa: Verbinum, 2007.

Zoll, Andrzej. „Człowiek jako podmiot wolności i praw w jednoczącej się Europie”. W: Człowiek w jednoczacej się Europie, red. Anna Królikowska, 45-56. Kraków: WSFP Ignatianum, WAM, 2004.

Żmudziński, Wojciech. „Fundament ignacjańskiej pedagogiki”. W: Pedagogika ignacjańska wobec wyzwań współczesnego humanizmu, red. Wit Pasierbek, 51-64. Kraków: WSFP Ignatianum, WAM, 2008. 